\title{
Does Ecuador Comply with International Tax Information Exchange Standards Required to Apply the Multilateral Agreement on Mutual Administrative Assistance in Tax Matters?
}

\author{
Gabriela Rivadeneira Chacón \\ Correspondence: Gabriela Rivadeneira Chacón, AVL Abogados, Quito, Ecuador. \\ Received: April 16, 2021 \\ Accepted: April 30, 2021 \\ Online Published: May 27, 2021 \\ doi:10.11114/ijlpa.v4i1.5214 \\ URL: https://doi.org/10.11114/ijlpa.v4i1.5214
}

\begin{abstract}
The exchange of tax information is essential to prevent fraud and tax evasion. Accordingly, states and international organizations have developed international conventions regarding the exchange of tax information. One example is the Multilateral Convention on Mutual Administrative Assistance in Tax Matters. Some States, including Ecuador, have signed and ratified this Convention. However, it is unclear whether Ecuador currently meets almost all Convention's requirements.

In this article, I investigated the Ecuadorian regulations and showed that Ecuador complies with most of the Convention's standards. However, Ecuador does not have a specific comprehensive law that regulates information exchange. Therefore, Ecuador should develop policies and norms that exclusively regulate tax information exchange to facilitate practical information exchanging with other tax authorities.
\end{abstract}

Keywords: tax information exchange, tax authorities, standards, access to information, confidentiality, bank information, information exchange mechanisms

\section{Methodology}

We used a qualitative descriptive-analytical approach since a detailed analysis of the Multilateral Convention on Mutual Administrative Assistance in Tax Matters. We would later assess the generalities of tax information exchange. This study will subsequently use applicable information exchange standards to develop an analytical study to evaluate Ecuador's information availability, access to bank information, confidentiality and information exchange mechanisms standards compliance levels.

\section{Results}

Ecuador has regulations that permit tax authorities to access information from accounts, accounting, taxpayers' bank information, and transactions conducted within Ecuadorian territory. In addition, Ecuador has adequate sufficient tools to facilitate the exchange of tax information. However, Ecuador does not fully comply with confidentiality standards since there were no procedures or protocols to adequately regulate all aspects of information custody and security at the close of this study.

\section{Introduction}

This article analyzes the Multilateral Convention on Mutual Administrative Assistance in Tax Matters and the particularities, types, and mechanisms of information exchange.

Subsequently, we will conduct a study on the standards applicable to the exchange of information to determine whether the Ecuadorian State complies with these standards and describes its capacity to exchange information with other tax authorities effectively.

\section{The Multilateral Convention on Administrative Assistance in Tax Matters}

The Multilateral Convention on Administrative Assistance in Tax Matters (hereinafter the " Convention ") was developed by the Organization for Economic Cooperation and Development (hereinafter the "OECD") and the European Council in 1988. However, in 2010, the Protocol of Amendment was modified to adapt it to international standards and open the Convention to third States that are not part of the Council of Europe or the OECD. Thus its new denotation was the Convention on Mutual Administrative Assistance in Tax Matters (Falcon and Pulido 2013, p. 208). 
The Convention signing and enforcement process began on January $25^{\text {th }}, 1988$, and April $1^{\text {st }}, 1995$, in ten countries (Falcón and Pulido 2013, pp. 207 and 208). Its main objective is to provide administrative assistance to tax authorities in different countries. In this regard, Falcon and Pulido (2013, p. 208) argue:

The objective of the agreement is the provision of mutual administrative assistance (including the execution of judicial decisions), with the following content: a) exchange of information, including simultaneous tax inspections of the same taxpayer in two or more countries and participation in inspections, carried out abroad; b) assistance in collection, including the adoption of precautionary measures; and c) service of documents on behalf of another State.

According to the OECD, this Convention is the complete existing regulation for all forms of tax cooperation that seek to deal with tax avoidance and evasion. Furthermore, this Convention consolidates "the high standard of transparency and information exchange for the purposes of the OECD project of harmful tax competition" (Bereijo and Leon 2012, p. 8).

The updated Convention has 32 articles divided into six chapters: (i) Chapter 1 refers to the Convention's application scope; (ii) Chapter 2 contains general definitions required to apply the Convention; (iii) Chapter 3 regulates the information exchange mechanism between tax authorities; assists in the collection of tax credits and notification or transfer of documents; (iv) Chapter 4 contains provisions regarding all forms of assistance and above all establishes compulsory guidelines for the exchange of information between tax authorities; (v) Chapter 5 contains special provisions regarding Convention implementation and; (vi) Chapter 6 contains norms regarding the signature, enforcement, territorial application, reservations, denunciations, and deposition of the instrument of ratification of the Convention.

The Ecuadorian State ratified the Convention on August $26^{\text {th }}, 2019$, and enforced it on December $1^{\text {st }}, 2019$. Consequently, the Convention is fully and directly applicable to the Ecuadorian legal system.

\section{The Exchange of Tax Information}

The exchange of tax information relates to sharing taxpayer financial information, including cross-border transactions and their assets (Velasco Mancheno and Castaneda Florez 2017, pp. 99-100). According to Rosembuj (2003, p. 13). The purpose of this exchange serves "the supply of acts, data, documents that are useful to the tax systems involved."

Information is exchanged to prevent tax collection losses when tax authorities are unaware of the income obtained by their taxpayers residing in other States (Rosembuj 2014, p. 32). In addition, although international businesses exist, tax authorities are limited to their jurisdictions but may partly inspect the global operations of their taxpayers (Pecho Trigueros 2014, p. 32).

Tax administrations must cooperate to identify taxpayers' activities and capital investments in different countries. Through such a collaboration, tax authorities can limit tax avoidance (Adonino 2013, p. 569).

Tax information can be exchanged:(i) by incorporating clauses to prevent double taxation in agreements; (ii) using specific international agreements; and (iii) employing international judicial assistance agreements that assist where there are tax crimes (Pita 2007, p. 15).

Some authors recognize various forms of information exchange: (i) upon request; (ii) automatically; (iii) spontaneously; (iv) for inspection abroad; (v) information concerning an industry; (vi) simultaneous tax inspection; and (vii) by way of group request (Lang 2014, pp. 203 and 204). Next, this article will explain each of these mechanisms.

a) Exchange of information upon request: a State makes a specific request for information to another State. This request must detail what information is required and why it is required. This modality is considered a supplementary resource that States can only use after exhausting all other means for obtaining this information (Pita 2007, p. 27).

b) Automatic information exchange: this modality involves the periodic supply of specific types of information. Tax authorities usually obtain this type of information about income or operations without asking for it (Pita 2007, p. 27).

c) Spontaneous exchange of information: this occurs when two or more States mutually transmit information between or among each other when a State comes across information that may be relevant to the other State's administration. For example, the data shared may pertain to a resident's actions, operations, or relationships linked to their tax obligations in another country (Pita 2007, p. 27).

d) Tax inspection abroad: tax officials from one State take part in inspection tasks carried out by the tax authorities of another State (Pita 2007, p. 27).

e) Exchange of information about an industry: in this mode, data regarding a sector of a particular economic activity is shared with another state. This mechanism allows the States to know the trends and evasion schemes, price policies, and industries' financial schemes (Pita 2007, p. 27).

f) Simultaneous tax inspection: occurs when each tax administration carries out inspections in their territory to review taxpayer information or operations of interest to the States (Pita 2007, p. 27). 
g) Group request: a State requests for information regarding a group of taxpayers (and not individual taxpayers) and must provide a detailed description of the group and the facts and circumstances underlying its request (Lang 2014, p. 204).

In most cases, the exchange of tax information is subject to an existing international agreement to avoid double taxation (Bereijo León 2012, p. 7).

\section{The Exchange of Tax Information Under the Convention}

The Convention states that tax authorities can exchange any information that is potentially relevant to another tax authority. Article 4 of the Convention grants tax administrations the power to inform their residents or nationals about a request for information before sharing any data. The Convention recognizes the following mechanisms:

First, article 5 of the Convention directs that the requesting State makes a formal request. Additionally, this article compels the requested State to take the necessary measures to provide the requesting State with the information in question.

Second, the automatic information exchange mechanism is the systematic sharing of specific information types relevant to each State (Convention, article 6).

Third, spontaneous exchange of information occurs when data is sent to another State without a prior request under the following circumstances: (a) there are reasons to suspect a loss in tax revenues in the recipient State; (b) a taxpayer has obtained a reduction or exemption that would increase his or her payable tax in the recipient State party; (c) business agreements conducted in one or more States between a person subject to tax in one State and another person subject to tax in a different State party may results in tax savings for either or both parties; d) a State party has reason to suspect that the artificial transfers of profits within a group of companies may result in tax savings and; e) if the information sent can be used to determine tax payment obligations (Convention, article 7).

Fourth, simultaneous tax audits, with agreements between two or more parties, to concurrently examine each territory's tax status, or persons of common interest, transactions and to exchange the information obtained from the audits. Two or more States can only carry out simultaneous tax audits at the request of a State party to the Convention (Convention, article 8).

Fifth, with tax audits abroad, a State allows representatives of another State authority to conduct a tax audit in its territories in a relevant component of a tax audit. The interested State must submit a request which, if approved, will be notified of the time, place, designated officials, the procedures, and conditions required for the audit (Convention, article 9).

Finally, article 22 of the Convention places the onus on the States to protect and maintain information confidentiality in the following terms:

Any information obtained by a Party under this Convention shall be treated as secret in the same manner as information obtained under the domestic laws of that Party, or under the conditions of secrecy applying in the supplying Party if such conditions are more restrictive.

Such information shall, in any case, be disclosed only to persons or authorities (including courts and administrative or supervisory bodies) involved in the assessment, collection or recovery of, the enforcement or prosecution in respect of, or the determination of appeals concerning taxes of that Party. Only the persons or authorities mentioned above may use the information and then only for such purposes. Notwithstanding the provisions of paragraph 1, they may disclose it in public court proceedings or in judicial decisions relating to such taxes, subject to prior authorization by the competent authority of the supplying Party. However, any two or more Parties may mutually agree to waive the condition of previous authorization.

\section{Standards Applicable to the Exchange of Information}

States developed the standards applicable to the exchange of information based on the OECD's reports and the Model Agreement on Exchange of Information in Tax Matters (Falcon and Pulido 2013, p. 222).

The Global Forum on Transparency and Information Exchange consists of the multilateral legal framework in transparency and information exchange of approximately 100 States (Implementing the Tax Transparency Standards 2011, p. 7). The Global Forum monitoring and review done by other States ensures compliance with applicable standards for transparency and tax information exchange. This section examines all the standards applicable to tax information exchange identified by the Global Forum.

\subsection{Availability of and Access to Information}

The information availability standard requires that all States access information related to partners and companies' information incorporated, receive income, deductions, credits, or carry out economic activities in their jurisdiction (Global Forum 2011, p. 25). This requirement guides the storage of information related to transactions, documentation, amounts of money received and spent, all the sales and purchases made by the entity, and all the entity's assets and liabilities 
(Forum Global 2011, p. 26). Finally, States should store this information for approximately five years (Global Forum 2011, p. 26).

The Global Forum believes that effective exchange of information for tax purposes depends on readily available data, reliable, relevant to a specific tax authority. Furthermore, there must be legal mechanisms that permit tax authorities to exchange and obtain information (Joint Ad Hoc Group of Accounts 2005, p. 58). Hence information access grant that tax authorities' power to obtain and deliver information held by banks, financial institutions, or any person acting as an agent or trustee or other entities to other states (Global Forum 2011, p. 27). The States signed to the Convention must have adequate measures to guarantee information access by a tax administration (Foro Global 2011, p. 28). Notably, this standard, in principle, does not allow a State to reject a request for secretive information. Furthermore, a State's existing rights and safeguards should not prevent or delay the effective exchange of information.

These two standards are summarized to fulfill the following measures:

a) Maintenance of reliable accounting records: accounting records must accurately explain and detail transactions, must be carried out within a reasonable time and must include underlying documentation such as invoices, contracts, and supporting documents to be considered reliable (Joint Ad Hoc Group of Accounts 2005, p. 59).

b) States must keep accounting records for a minimum period of generally five years (Joint Ad Hoc Group of Accounts 2005, p. 60).

c) Countries must implement a system or structure that guarantees that accounting records will be maintained (Joint Ad Hoc Group of Accounts 2005, p. 60).

d) Access to accounting records: when a State party requests a third Party's accounting records, the tax authorities governing the third Party's accounts must provide this information within a reasonable period. These tax authorities may also penalize persons or entities who refuse to provide information in their possession (Joint Ad Hoc Group of Accounts 2005, p. 61).

\subsection{Access to Banking Information}

When it is impossible to access taxpayers' bank information, tax authorities are unaware of a taxpayer's income and resources that may have been hidden from the tax authorities, possibly through covert banking (Global Forum 2000, $p$. 29). Moreover, at the international level, the absence of tax information can distort capital and financial flows due to harmful tax competition (Global Forum 2000, p. 31).

The "Improving Access to Bank Information for Tax Purposes" report proposes an important tax information exchange standard. States should allow tax authorities to access bank information directly or indirectly "for any tax reason so that they can fully fulfill their mission of tax collection and carry out efficient exchanges of information" (Global Forum 2000, p. 10).

The report recognizes the importance of bank secrecy and the severe consequences that may result from accidental access to this type of information. Thus the report suggests that access to banking information be supervised under strict precautions to ensure that the data is used only for specific purposes (Global Forum 2000, p. 19).

This report, therefore, imposed a series of measures for States to adopt to comply with the information exchange standards for banking information. The main measures to adopt are:

a) The prohibition of anonymous bank accounts.

b) The need for banking institutions to identify regular and occasional bank customers and other people that may benefit when a bank account is opened or when a transaction is carried out.

c) Analyze any domestic restrictions that prevent the tax authorities with access to bank data from sending tax information upon request to another tax authority within the context of an agreement or treaty that permits the exchange of tax information.

d) Review the policies and practices that do not allow tax authorities to access banking information directly or indirectly for tax purposes.

Finally, it is essential to note that in 2014, OECD member countries and the G20 developed the Common Reporting Standard that permits the automatic exchange of financial information between states (Global Forum 2020 p. 7).

\subsection{Confidentiality of Information}

The "Keeping it Safe: The OECD Guide on the Protection of Confidentiality of Information Exchanged" report highlights the importance of keeping taxpayer's information private. Tax authorities must assure taxpayers they will not voluntarily nor accidentally share their sensitive financial and confidential information with third parties (Global Forum 2012, p. 5). 
To guarantee that taxpayer's information is kept confidential, States must enact internal legislation rules the disclosure of information obtained under a tax treaty or other exchange information instrument between tax administrations. Similarly, countries must have exceptions to individual freedoms that may limit disclosure (Global Forum 2012, p. 12).

This report also recommends that workers or officials who have access to the information obtained through tax exchange must have undergone verification and security evaluation to certify that they do not become a security risk to the company. Therefore, contracts that regulate employees' confidentiality obligations extend this responsibility beyond the contractual relationship and impose sanctions for the breach of the confidentiality obligation should be drawn up (Global Forum 2012, p. 17).

Similarly, tax authorities must limit access to their facilities, especially to areas where confidential files are located, and employ a security system to restrict access to electronic files (Global Forum 2012, p. 18). Moreover, tax authorities must have adequate information destruction policies.

Before sending any information, a requested State must ensure that the recipient State will keep data sent confidentially. Data must be sent through a secure platform or as encrypted documents in an email attachment where automatic information exchange occurs. The sending administration must record the information recipient, the number of copies shared, and the recipient officials' particulars (Global Forum 2012, p. 23).

There are also measures that each State's competent authorities must adopt. Thus, the recipient tax administration must enter the information in an independent database only accessed by authorized officials with individual login details and passwords (Global Forum 2012, p. 25).

The Ecuadorian State has been part of the Global Forum since April 26th, 2017; therefore, in principle, Ecuador is bound to the standards and provisions mentioned above. Applying these standards is essential to comply with the Convention and to exchange information between tax authorities effectively.

\section{Ecuador's Standards Compliance}

This section describes how the Ecuadorian State complies with the standards mentioned in section 4 and proposes measures to comply with these standards and effectively use the Multilateral Convention on Mutual Assistance.

\subsection{Availability of and Access to the Information}

Article 37 of the Regulation for the Application of the Internal Tax Regime Law (hereinafter referred to as "Regulation to the LRTI") states that taxpayers are obliged to keep accounts must retain their accounting documents for a minimum of seven years. Similarly, article 38 of the same legal body directs taxpayers already compelled to preserve income and expense accounts to keep all supporting documents of income and expenses for a minimum period of seven years. Therefore, the Ecuadorian legislation complies with the information availability standard.

Likewise, all taxpayers are required to keep accounting or income and expense accounts with all their supporting documentation for their operations for a minimum period of seven years. These tax provisions demonstrate that Ecuador exceeds the international standard that states must keep such documents for five years.

As regards access to information, the Tax Code in article 96 obliges taxpayers to provide authorized officials with inspections or verifications for tax computation tax and: "Show the respective officials, the statements, reports, books, and documents related to the events that give rise to tax obligations and formulate the clarifications that may be requested."

Similarly, article 98 of the Tax Code prescribes that any natural person or a legal person's representatives must provide information or display documents in their possession to the tax administration. However, when this obligation is imposed on third parties, it is conditional to determine the tax obligation of another taxpayer. Therefore, it is questionable whether a tax administration can use this article to request a third parties' information from another taxpayer for purposes other than those provided by law to exchange tax information with another administration.

\subsection{Bank and Financial Information}

This standard imposes on the States the obligation to adopt measures that allow tax authorities to access taxpayers' bank information. Ecuadorian legislation meets this standard for the following reasons:

First, article 352 of the Organic Monetary and Financial Code establishes that the data of the users of the financial system can only be delivered to their holders to its owners or authorized persons.

Second, article 354 of this law establishes specific exceptions to article 352; one of these rules is the Internal Revenue Service requirement (the "IRS") for information exchange.

Third, financial institutions that are part of the popular and supportive financial sector should require their partners or customers to sign an express authorization. This authorization empowers financial institutions to deliver financial information to the control bodies and the IRS to comply with international information exchange agreements or 
conventions ratified by Ecuador and their respective protocols or agreements between competent authorities and ensure reciprocity and confidentiality (Resolution No. SEPS-IGT-INGINT-INR-IGJ-2020-0152).

Fourth, the IRS issued Resolution No. NAC-DGERCGC19-00000045 that was renovated in 2021 by Resolution No. NAC-DGERCGC21-00000006, obliges custodial institutions, depository institutions, investment companies, and certain insurance companies to file Schedule of financial accounts of non - residents. These files concern information about dividends, account balances, income from certain insurance products, revenue account from the sale of financial assets, and other income generated by assets held in an account belonging to individuals or companies that are not tax residents in the country.

In conclusion, Ecuador complies with the international standard for the access to and availability of banking and financial information. Ecuador's SRI is legally empowered to access and request banking information on taxpayers. Also, banking institutions must maintain a registry that contains the identity of their clients and financial operations and the responsibility to report certain information that may be of interest to the tax administration.

\subsection{Confidentiality of Information}

States must guarantee that the information exchanged is kept confidential as per the internal legislation of each State. In Ecuador's case, no provision ensures that information obtained through tax information exchange is kept private. However, in the Ecuadorian legislation, the following regulations protect certain tax information:

First, article 99 of the Tax Code guides the confidentiality of tax information and indicates which taxpayers', managers', or third parties' statements and information are related to tax obligations.

Second, article 101 of the Internal Tax Regime Law states that taxpayers', managers', or third parties' statements and information are reserved and can only be used for tax administration purposes.

In third place, in early 2021, the IRS issued Circular No. NAC-DGECCGC21-00000003 prohibits anyone, including officials and former officials of the tax authorities, who currently has or previously had access to information to maintain such reserves from publishing or disclosing such information.

Ecuador partially complies with the confidentiality standard. In addition, Ecuador's legislation contains provisions for preserving and protecting taxpayer declarations and information and prohibiting disclosure, publication, and misuse of reserved tax information by third parties, officials, and former officials of the tax administration.

However, Ecuadorian law does not comply with the confidentiality standards for SRI protocols and procedures for compiling, handling, retaining, and sending tax information. After reviewing public sources, the Ecuadorian tax administration does not have adequate regulations to handle data that has been exchanged between tax authorities. Therefore, the SRI must draw up internal rules to place information to be exchanged in a physical space that is inaccessible to unauthorized officials or third parties. This regulation must also contain adequate technological measures that guarantee information security. Furthermore, SRI officials' employment contracts must contain clauses that guarantee the nondisclosure of information and establish sanctions in the event of non-compliance.

\subsection{Information Exchange Mechanisms}

This standard refers to legal tools to facilitate information exchange between tax authorities, as explained in Chapter II. These mechanisms are agreements to prevent double taxation that contain an exchange clause or are multilateral tax assistance conventions.

In Ecuador's case, there are 19 Agreements with the following States to prevent double taxation: Germany, Belarus, Belgium, Brazil, Canada, Chile, China, Korea, Spain, France, Italy, Japan, Mexico, Qatar, Romania, Russia, Singapore, Switzerland, and Uruguay.

Ecuador has a vast network of agreements that contain an information exchange clause and multilateral contracts to avoid double taxation. Furthermore, as a member state of the Andean Community, Ecuador is bound by Decision 578 on the Regime to Avoid Double Taxation And Prevent Tax Evasion that empowers States to exchange information and establish necessary controls to prevent tax evasion and fraud.

Additionally, Ecuador signed and ratified the Convention that imposes obligations on States Parties to exchange tax information between their tax authorities.

Therefore, Ecuador has mechanisms to exchange tax information comprising agreements to avoid double taxation, i.e., information exchange clauses and international instruments that oblige States parties to exchange tax information.

\section{Conclusion}

The Convention is undoubtedly a critical tool in the States' fight against tax evasion and fraud that endeared Ecuador to sign and ratify the Convention on Mutual Assistance in Tax Matters. 
For practical information exchange, Ecuador should comply with international standards that regulate information exchange for all States party to the Convention. This standard obliges the States to adopt measures that allow tax authorities to access taxpayers' bank information. Ecuadorian legislation meets this standard in the following ways:

First, article 352 of the Organic Monetary and Financial Code directs that a state can only share financial system users' data with individual users or authorized persons.

Second, article 354 of the same law lists specific exceptions to article 352, for instance, the IRS for information exchange.

Third, financial institutions belonging to the popular and supportive financial sector usually request their partners or customers to sign an express authorization that empowers these institutions to deliver partners' or customers' financial information to the control bodies and the Internal Revenue Service. This requirement complies with international information exchange agreements or conventions ratified by Ecuador and their respective protocols or agreements between competent authorities and ensures reciprocity and confidentiality (Resolution No. SEPS-IGT-INGINT-INR-IGJ2020- 0152).

Fourth, the IRS issued Resolution No. NAC-DGERCGC19-00000045 and renovated in 2021 by Resolution No. NACDGERCGC21-00000006, compels custodial institutions, depository institutions, investment companies, and certain insurance companies to file a Schedule of financial accounts for non - residents. This requirement applies to reports related to dividends, account balances, income from certain insurance products, revenue accounts from the sale of financial assets, and other income generated by assets held in an account belonging to individuals or companies who are not tax-paying residents in a country.

In conclusion, Ecuador complies with the international standard for access and availability of banking and financial information. Ecuador's SRI is legally empowered to request for and have access to taxpayers' banking information. SRI also directs banking institutions to maintain a client's registry containing their financial operations, and report information of interest pertaining to more than one States' tax authorities to Ecuador's tax authorities.

Having belonged to the Global Forum since 2017, Ecuador applies standards established by the Global Forum. Therefore, Ecuador's tax laws compel all taxpayers to prepare accounting records and keep all their supporting documents for a minimum of seven years.

Regarding the possibility of tax authorities accessing taxpayers' information, taxpayers should avail the information required if it is for determination purposes only. Therefore, it is advisable to include the possibility that the data is used for information exchange purposes by the Ecuadorian tax administration.

An additional applicable standard is an access to bank information. As demonstrated in chapter 8.2, the SRI can access taxpayers' bank information and data even if it is for information exchange purposes only. Therefore, all financial institutions must maintain records on clients' identity, ownership of accounts, and clients' bank transactions and report certain transactions carried out by non-residents the SRI.

Ecuador partially complies with confidentiality standards. The country's taxpayers' information (and their respective returns) is considered private and cannot be disclosed to unauthorized persons by third parties. These third parties may include current and former officials of the tax administration.

Finally, Ecuador has information exchange mechanisms that include clauses in several agreements and multilateral instruments which prevent double taxation.

Ecuador complies with most of the Convention's standards and regulations regarding tax information exchange with other tax authorities. However, specific rules that exclusively regulate the information exchange should be developed because the existing general tax regulations may not be sufficient to avoid cause confusion and inconvenience.

\section{References}

Adonino, P. (2003). The exchange of information between tax administrations. Course on International Tax Law. Tomo II, Bogota: Temis.

Bereijo León, M. (2012). The exchange of tax information between the States and its evidentiary incidence. ImDret: Barcelona.

Ecuadorian Internal Revenue Service. Resolution No. NAC-DGERCGC19-00000045.

Ecuadorian Organic Monetary and Financial Code.

Ecuadorian Regulation for the Application of the Internal Tax Regime Law.

Ecuadorian Tax Code.

Falcón, Tella, R., \& Pulido Guerra, E. (2013). International Tax Law (2nd ed.). Madrid: Marcial Pons. 
Global Forum. (2000). Improving Access to Bank Information for Tax Purposes. 2000 [consulta: junio de 2019]. Retrieved from https://www.oecd.org/tax/transparency/about-the-globalforum/publications/improvingaccesstobankinformationfortaxpurposes.htm

Global Forum. (2000). Towards Global Tax Co-operation: Report to the 2000 Ministerial Council Meeting and Recommendations by the Comitee on Fiscal Affairs. Retrieved from https://www.oecd.org/tax/transparency/aboutthe-global-forum/publications/towards-global-tax-cooperation-progress.pdf

Global Forum. (2005). Enabling Effective Exchange of Information: Availability and Reliability Standard. Retrieved from https://www.oecd.org/tax/transparency/about-the-global-forum/publications/44654766.pdf

Global Forum. (2012). Keeping it Safe. The OCDE Guide on the Protection of Confidentiality of Information Exchanged for Tax Purposes. Retrieved from http://www.oecd.org/ctp/exchange-of-tax-information/keeping-it-safe-report.pdf

Internal Revenue Service. Circular No. NAC-DGECCGC21-00000003.

Internal Revenue Service. Resolution No. NAC-DGERCGC21-00000006.

Lang, M. (2014). Introduction to the Law of the Agreements to Avoid Double Taxation. Bogota: Temis.

Merino Espinosa, M. P., \& Nocete Correa, F. J. (2011). The exchange of tax information: between normative diversity, conceptual imprecision and plurality of interests. Cronica Tributaria, num. 139-2011. Retrieved from https://www.economistas.es/contenido/REAF/gestor/139/139_Merino.pdf

Multilateral Convention on Mutual Administrative Assistance in Tax Matters.

Pecho Trigueros, M. E. (2014). Automatic exchange of information: towards a new global.

Pita, C. (2007). The Exchange of Tax Information as an Instrument to contain unfair competition at the International Level. Interamerican Development Bank.

Rodriguez, M., \& Bereijo, L. (2012). The exchange of tax information between the States and its evidentiary incidence. Madrid: Universidad Autonoma de Madrid.

Rosembuj, T. (2003). Exchange of tax information. Barcelona: Ediciones de la Universitat de Barcelona. Standard of tax transparency. Revista de la Facultad de Derecho, num 71.

Velasco Mancheno, C., \& Castaneda Florez, C. (2017). Strengthening the exchange Information Center to Combat Income Tax Fraud: Comparative Case Study between Ecuador and Chile. Santiago de Chile: FORO Revista de Derecho, no. 28.

\section{Copyrights}

Copyright for this article is retained by the author(s), with first publication rights granted to the journal.

This is an open-access article distributed under the terms and conditions of the Creative Commons Attribution license which permits unrestricted use, distribution, and reproduction in any medium, provided the original work is properly cited. 